\title{
Absence of Pseudomonas syringae pv. actinidiae in kiwifruit leaves and flowers from Buenos Aires Province, Argentina.
}

\author{
M.C. Sánchez ${ }^{1,2 a}$, G. E. Clemente ${ }^{1}$, A. K. Yommi ${ }^{3}$, A. M Alippi ${ }^{2,4}$ and A. del C. Ridao ${ }^{1}$ \\ Unidad Integrada Balcarce (1FCA-UNMdP/3INTA EEA Balcarce), Balcarce, Argentina; \\ ${ }^{2}$ Comisión de Investigaciones Científicas, CIC; ${ }^{4}$ FCAyF-UNLP, La Plata. Argentina.
}

\begin{abstract}
Argentina has around 1000 ha of kiwifruit orchards in Buenos Aires Province. This country is recognized as free of Pseudomonas syringae pv. actinidiae (Psa). In 2013, the National Sanitary Service (SENASA) imposed measures to avoid the entrance of this pathogen to the kiwifruit production areas. In this way, a vigilance plan was established and the introduction of plant material was regulated. In March 2015, three infected samples with Psa were detected in orchards at the South-East of Buenos Aires Province and they were immediately eradicated by SENASA. The objective of this work was to identify the bacteria associated with kiwifruit leaf spots and flower blights in commercial orchards of Actinidia deliciosa 'Hayward' at Buenos Aires Province, during the 2015-2016 growing season. On spring and autumn seasons, plant tissues were collected from a 100 ha area located in the North and South-East of this Province. Bacterial isolates were obtained from flowers and leaves by tissues mashing and inoculation on nutrient agar supplemented with $5 \%$ sucrose (NSA). The primary identification of isolates was performed by biochemical and physiological tests. To confirm their identity, duplex-PCR tests were performed, including negative and positive controls (no template and Psa DNA, respectively). From symptomatic and asymptomatic samples, 120 bacterial isolates were obtained. Thirty of these isolates were morphologically similar to Psa, forming white-creamy, convex, domed and mucoid colonies on NSA. Also, all of them were Gram-negative, produced a green fluorescent pigment on King's B medium and their metabolism was aerobic. However, none of these strains examined produced any bands following the amplification by PCR with Psa specific primers. Our results show the absence of Psa in the analyzed samples. Further studies are needed to identify these non-Psa bacteria associated with kiwifruit leaf spots and flower blights.
\end{abstract}

Keywords: Actinidia deliciosa, 'Hayward', bacterial canker, quarantine pest

\section{INTRODUCTION}

The kiwifruit (Actinidia deliciosa (A. Chev.) C. S. Liang et. A.R. Ferguson) production has had a sustainable growth during last decade in Argentina. The main area of this crop is concentrated in the South-East of Buenos Aires Province (departments of Balcarce, General Alvarado, General Madariaga, General Pueyrredón and Mar Chiquita) and at the North (departments of Baradero, La Plata, Mercedes and San Pedro) (Benés et al., 2014). At the South-East of Buenos Aires Province, there is an area of 440 hectares of kiwifruits orchards, representing around $50 \%$ of the national production (Yommi, pers. commun.). Most of the national area is planted with the kiwifruit 'Hayward' that has excellent postharvest attributes and organoleptic characteristics (Rushing, 2004).

a Email: sanchez.mariaclara@gmail.com 
Pseudomonas syringae pv. syringae (Pss), P. syringae pv. actinidiae (Psa), P. viridiflava and $P$. marginalis can cause necrotic and angular leaf spots, blossom blights and twigs cankers on kiwifruit (Wilkie et al., 1973; Young et al., 1988; Takikawa et al., 1989; Balestra and Varvaro, 1997; Mansilla and Abelleira, 1999; Gonzales and Rodicio, 2007; Balestra et al., 2010; Gallelli et al., 2011b). Psa kiwifruit bacterial canker is the most destructive and severe kiwifruit's disease (Donati et al., 2014). This bacterium was reported in most of the kiwifruit areas of the world (Scortichini et al., 2014). Severe epidemics and yield losses were reported in Chile, Italy, Japan, Korea, New Zealand, Portugal and Spain (Donati et al., 2014).

Actinidia spp. are the only known host plant species of Psa. These bacteria can be detected on both symptomatic and symptomless plants (Mazzaglia et al., 2010), in latently infected aerial plant parts and contaminated pollen (Vanneste et al., 2011). Infected plants and pollen are considered an essential way of the spread of the disease. The rain-splash and wind were the main mechanisms of the natural spread between and within vines (Tyson et al., 2014). The symptoms are present in aerial parts such us trunks, leaders, canes, leaves and flowers (Scortichini et al., 2012). The most typical symptoms of Psa are shoot-wilt; defoliation and dieback, with the presence of white to reddish-brown exudates trough the cankers. The leaves show small, angular, watersoaked areas which can later become necrotic and turn dark brown; a chlorotic halo is commonly observed around each necrotic spot. Similar symptoms might be caused on leaves by Pss. Also P. viridiflava has been reported as causing leaf necrotic spots, but without chlorotic halos (Scortichini, 1994; Balestra et al. 2010; Abelleira et al., 2011; Everett et al., 2011; Ferrante y Scortichini, 2009; Gallelli et al., 2011b). Psa causes browning of the sepals, flowers become necrotic and then can fall. In severe attacks, fruits can be dehydrated and reduce its development. All these symptoms cause important yield losses (KVH, 2011).

The genotypic, biochemical, and pathogenic variability of Psa was studied. Biovar 1 has been associated with severe epidemic events in Japan and Italy. Biovar 2 was reported only affecting orchards in South Korea. Pandemic strains of biovar 3 caused severe losses in Chile, Italy, New Zealand and China. Strains of these three biovars are considered virulent causing necrotic leaf spoting, canker and shoot die-back (Chapman et al., 2012; Vanneste, 2013; Ferrante and Scortichini, 2015). Biovar 4, described in Australia and New Zealand, is less virulent and was recently renamed as Pseudomonas syringae pv. actinidifoliorum pv. nov. (Cunty et al., 2015). These authors reported that only necrotic spots on leaves are the symptoms associated with this new pathovar.

In Argentina Psa is a quarantine pest, classified as A1. At 2013, the National Sanitary Service (SENASA, Servicio Nacional de Sanidad y Calidad Agroalimentaria) established a phytosanitary alert through the 589/2013 Resolution. In this way, the entrance of any kiwifruit vegetal parts was prohibited to avoid the introduction and dispersion of the pathogen. Since this moment, SENASA monitors orchards and nurseries with a systematic scheme of controls. In 2015, three positive samples at the South East of Buenos Aires Province were detected and those plants were immediately eradicated (SENASA, 2015).

The objective of this work was to identify the bacteria associated with kiwifruit leaf spots and flower blights in commercial orchards of A. deliciosa 'Hayward' at Buenos Aires Province, during the 2015-2016 growing seasons.

\section{MATERIAL AND METHODS Sampling}

Across the 2015 spring and the 2016 autumn, plant tissues were collected from a 100 ha area located in the North and South-East of Buenos Aires Province. Every orchard was inspected with a systematic and complete path. The whole group of plants on both sides of a line was examined (one line every three lines), taking a sample from a plant every 10 plants in the left side of the line. Leaves, sprouts and flowers (healthy and symptomatic) were collected. The samples were conditioned to be carried to the 
laboratory in plastic bags inside a cooled basket, and they were stored at $4^{\circ} \mathrm{C}$ for no more than 3 days before the analysis.

\section{Isolation}

The isolation was performed from macerated tissues in sterilized saline solution ( $0.85 \%$ w:v, sodium chloride:distilled water). Ten-fold dilutions were performed and the three last dilutions were streaked on Sucrose Nutrient Agar (SNA) (Kado and Heskett, 1970). The plates were incubated two days at $24{ }^{\circ} \mathrm{C}$. Macroscopic characteristics of colonies growing on SNA were assessed (length, form, arrangement, and Levan production). On King's B medium (King et al., 1954) the production of fluorescent pigments was detected.

\section{Primary identification}

The biochemical and metabolic profiles of the isolates were determined by the protocols established by Standard EPPO Diagnostics PM 7/120(1) (2014).

\section{PCR identification}

The identification of those isolates with biochemical and physiological profiles similar than the species Pseudomonas syringae was confirmed through PCR. A duplex-PCR reaction for detection of DNA specific fragments of Psa was performed to differentiate between pathovars syringae and actinidiae (Gallelli et al., 2011a).

\section{RESULTS AND DISCUSSION}

On October and November of 2015 six kiwifruits orchards were monitored, one in Balcarce, one in Gral. Alvarado and four in Gral. Pueyrredón. On April and May of 2016, tissue samples were collected in two orchards of La Plata, five orchards in Gral. Pueyrredón and another one in Balcarce (Fig. 1).

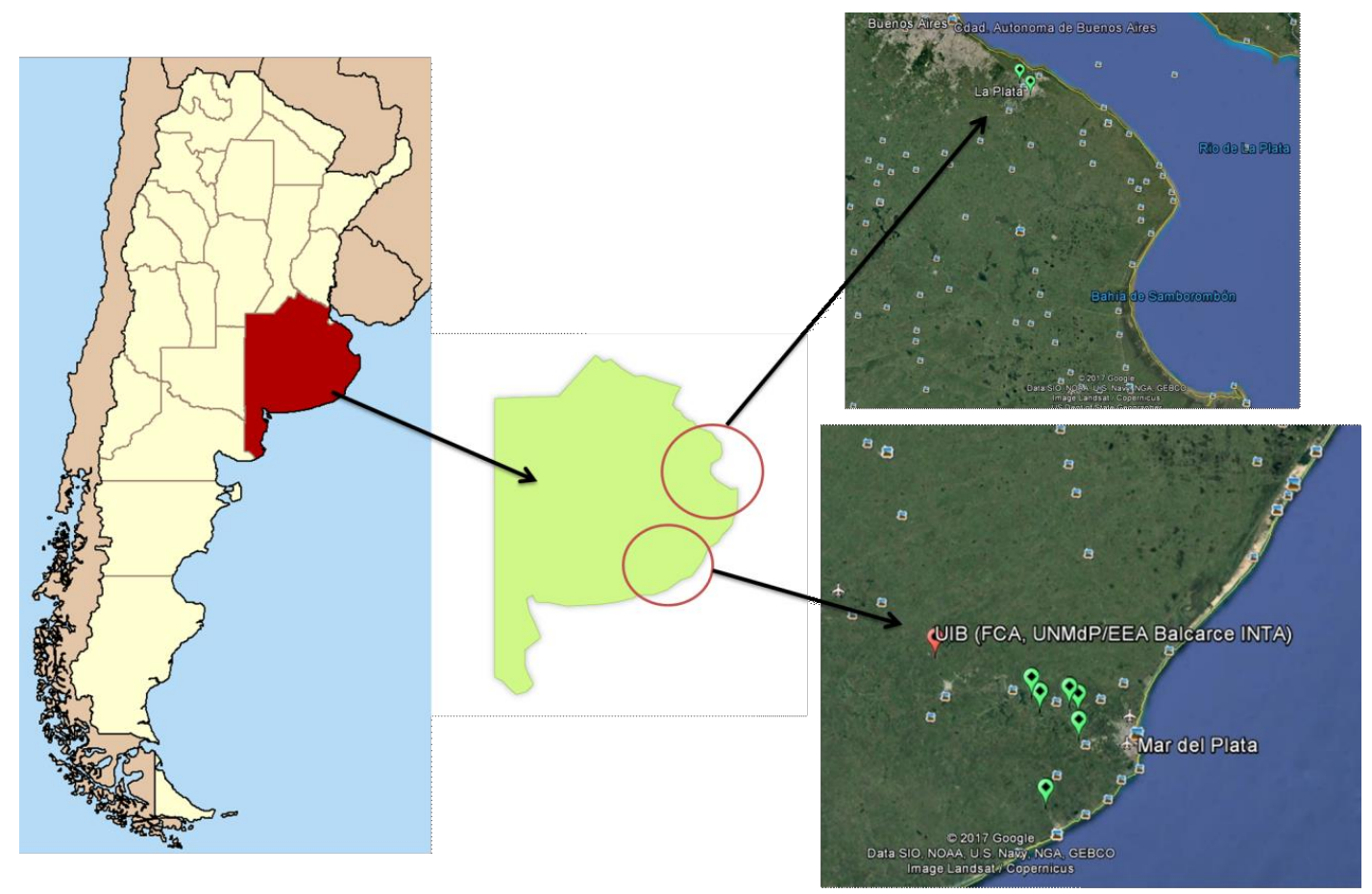

Figure 1. Location of the monitored orchards in the Buenos Aires Province, Argentina. The red mark indicates the location of our work place, where there is an experimental kiwifruit orchard too.

A total amount of already 200 tissue samples were collected in this study. One hundred and twenty isolates showing morphological characteristics described for $P$. syringae, were obtained from symptomatic organs and tissues without symptoms. The observed symptoms were small necrotic spots, angular in shape, some with chlorotic 
halos, necrotic and aqueous spots in sepals, as shown in Figure 2. The origin and the distribution of the isolates, according to the time of sampling and the organ where were isolated are shown in Table 1.

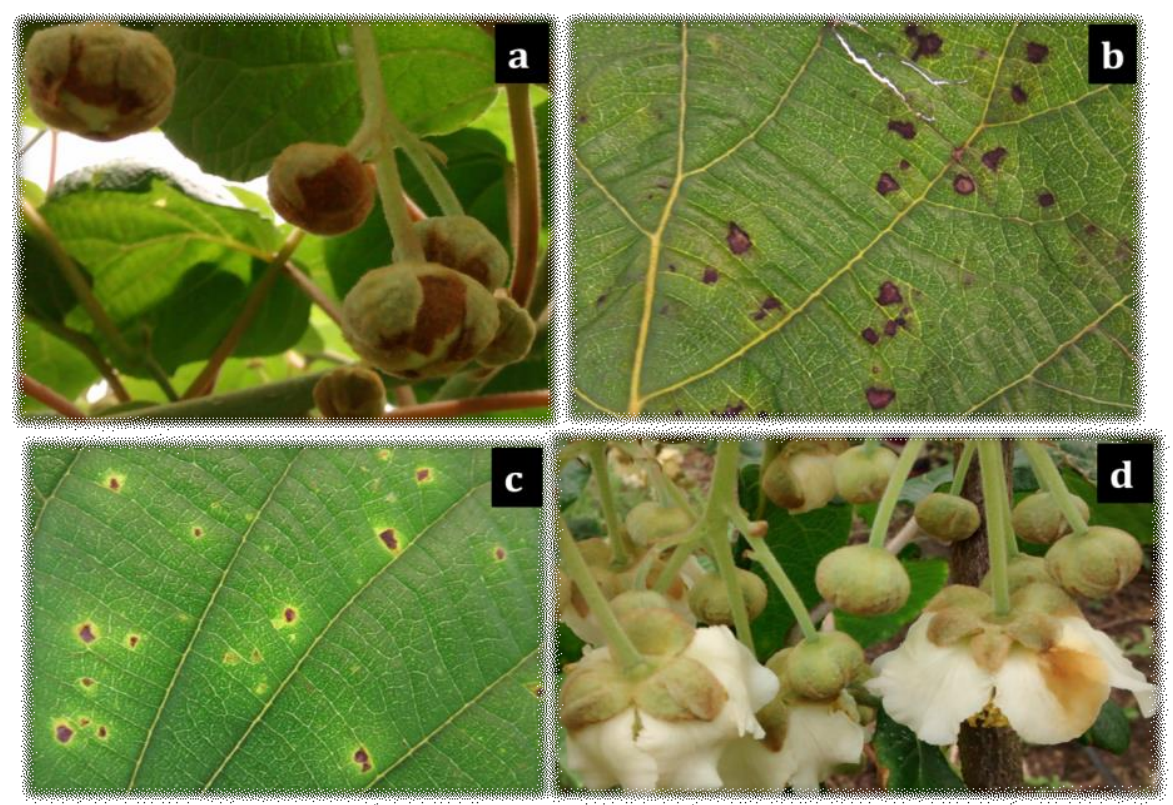

Figure 2. Different symptoms observed on the monitoring orchards of Actinidia deliciosa 'Hayward' at Buenos Aires Province, during 2015-2016 growing seasons. (a) necrotic spots in sepals; (b) small angular leaf spots without chlorotic halos; (c) angular leaf spots surrounded by chlorotic halos and (d) necrotic petals on flowers.

Table 1. Distribution of the isolates, according to the time of sampling and the part of the plant where were isolated.

\begin{tabular}{lccc}
\hline Monitoring season & Location & Vegetable organ & Isolets \\
\hline $\mathbf{2 0 1 5}$ Autumn & SE Bs As & Leaves & 15 \\
& Gral Alvarado & Leaves & 1 \\
& & Flower buds & 2 \\
& Batán, Gral Pueyrredón & Leaves & 2 \\
& & Flower buds & 4 \\
$\mathbf{2 0 1 5}$ Spring & Leaves & 5 \\
& & Flower buds & 1 \\
& & Flowers & 3 \\
& Sierra de los Padres, Gral Pueyrredón & Leaves & 6 \\
& Balcarce & Leaves & 0 \\
\hline & & TOTAL 2015 & 39 \\
& La Plata & Leaves & 29 \\
& Batán, Gral Pueyrredón & Leaves & 23 \\
& El Dorado, Gral Pueyrredón & Leaves & 13 \\
& Sierra de los Padres, Gral Pueyrredón & Leaves & 11 \\
& Balcarce & Leaves & 5 \\
\hline & & TOTAL 2016 & $\mathbf{8 1}$ \\
\cline { 2 - 4 } & & TOTAL & $\mathbf{1 2 0}$ \\
\hline
\end{tabular}


Seventy out of 120 isolates were Gram's negative and showed an oxidative metabolism of glucose. These isolates were considered presumptive Pseudomonas spp. (Goszczynska et al., 2000). Those isolates which showed Levan production in SNA medium (fluorescents and non-fluorescents) were classified as possible isolates of $P$. syringae (Takikawa et al., 1989; Scortichini, 1994). Thirty out of the 70 isolates showed the characteristics reported by Ferrante and Scortichini (2009), Everett et al. (2011) and EPPO (2014) for P. syringae. These colonies were greyish, pearly coloured, convex, circular with defined borders (Fig. 3). The isolates that were fluorescent but did not produce Levan were considered as P. viridiflava (Wilkie et al., 1973; Young et al., 1988; Balestra and Varvaro, 1997). P. marginalis can be differentiated from the other Pseudomonas species by positive reactions of oxidase and negative reaction in the hypersensitive tobacco test (Mansilla and Abelleira, 1999; Gonzales and Rodicio, 2007).

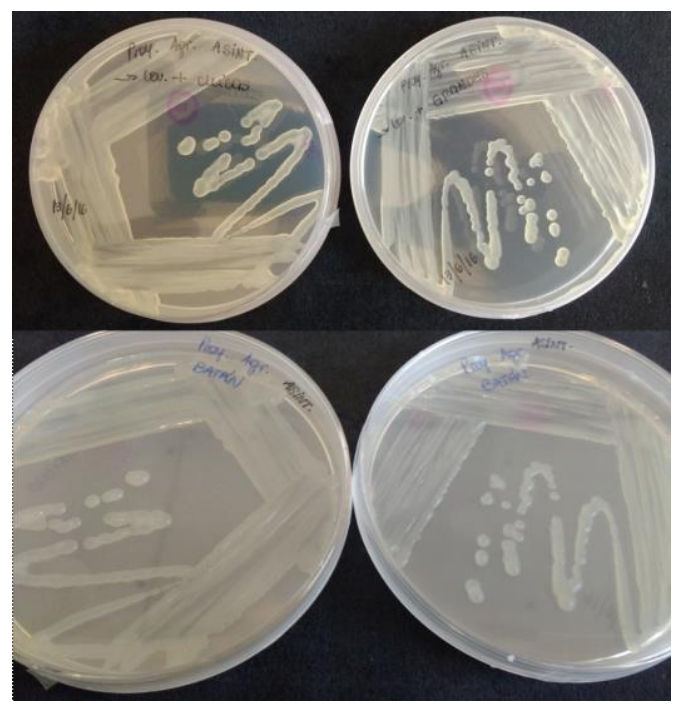

Figure 3. Some of the thirty colonies obtained from symptomatic leave tissues, classified as possible isolates of $P$. syringae. There were greyish, pearly coloured, convex and circular with defined border colonies.

The Pseudomonas fluorescent group can be classified through LOPAT probes: Levan production, oxidase, potato soft rot, arginine dihydrolase and HR on tobacco (Goszczynska et al., 2000). These tests are useful for a primary characterization of the isolates, but they are not sufficient to differentiate between Psa and Pss. Ferrante and Scortichini (2009) and Everett et al. (2011) described the morphology of Psa colonies in SNA medium as pearly to white, smooth, convex, circular, with defined borders.

Thirty isolates presumptive considered as P. syringae pathovars were analysed by duplex-PCR reaction to detect if they belong to Psa or Pss (Gallelli et al., 2011a). None of them showed the predicted PCR products of $492 \mathrm{bp}$ and $230 \mathrm{bp}$, respectively (Fig. 4). These results indicate the absence of Psa in the group of analysed samples. 


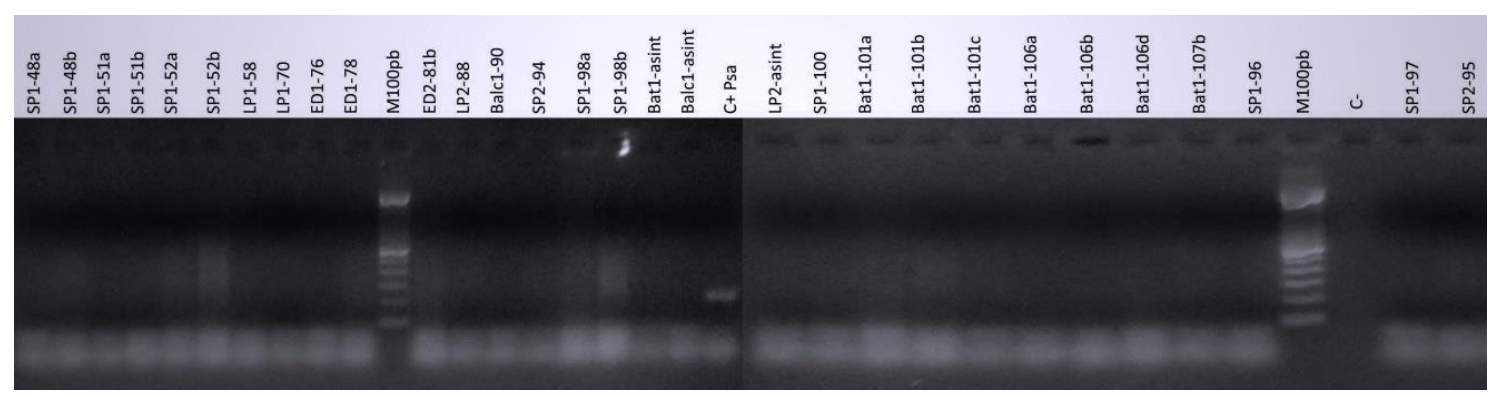

Figure 4. Gel electrophoresis analysis of duplex-PCR amplification by using primers KNF/R and Avr/DdxF/R (Gallelli et al., 2011a). Psa positive and negative controls were included (C+ Psa and C-, respectively).

Psa is the causal agent of the most damaging and severe disease of cultivated kiwifruits, but their symptoms are very similar to other Pseudomonas species reported on kiwifruit orchards. Further identification of these bacteria must be achieved.

\section{CONCLUSIONS}

- Pseudomonas species were isolated from kiwifruit leaf spots and flower blights in orchards of $A$. deliciosa 'Hayward' at Buenos Aires Province, demonstrating the presence of these pathogens in the studied area.

- Psa is not present in the analysed samples of kiwifruit from commercial orchards during the 2015-2016 growing seasons.

- Further studies are needed to identify the Pseudomonas species isolates.

\section{ACKNOWLEDGMENTS}

This work has been financially supported by Univ. Nacional de Mar del Plata, Argentina (UNMDP) (projects AGR517/16 UNMDP), Asoc. Coop. de la Fac. de Cs. Agrarias (FCA, UNMDP) and the Instituto Nac. de Tecnología Agropecuaria (INTA) (projects PNFRU1105083 and BASUR1272103). We wish to thank to Comisión de Investigaciones Científicas de la Prov. de Buenos Aires (CIC). The present work constitutes part of the Doctoral thesis of the first author, María Clara Sanchez, at the FCA-UNMdP.

\section{Literature cited}

Abelleira Argibay, A.A., López, M.M., Peñalver Navarro, J., Casal, O.A., Mansilla Vázquez, J.P. and Montoussé, A.P. (2011). First report of bacterial canker of kiwifruit caused by Pseudomonas syringae pv. actinidiae in Spain. Plant Disease 95(12),1593. http://dx.doi.org/10.1111/jam.12968

Balestra, G.M. and Varvaro, L. (1997). Pseudomonas syringae pv. syringae Causal Agent of Disease on Floral Buds of Actinidia deliciosa (A. Chev) Liang et Ferguson in Italy. J. Phytopathol. 145, 375378. http://dx.doi.org/10.1111/j.1439-0434.1997.tb00417.x

Balestra G.M., Renzi M. and Mazzaglia A. (2010). First report of bacterial canker of Actinidia deliciosa caused by Pseudomonas syringae pv. actinidiae in Portugal. New Dis. Rep. 22,10 http://dx.doi.org/10.5197/j. 2044-0588.2010.022.010

Benés, G., Viteri, L. and Yommi A. (2014). Kiwi marplatense: un negocio innovador. Complete paper presented at: 4to Congreso Regional de Economía Agraria y $45^{\circ}$ Reunión Anual de la AAEA (Buenos Aires, Argentina)

Chapman, J.R., Taylor, R.K., Weir, B.S., Romberg, M.K., Vanneste, J.L. and Luck, J. (2012). Phylogenetic relationships among global populations of Pseudomonas syringae pv. actinidiae. Phytopathol. 102, 1034- 1044. http://dx.doi.org/10.1094/PHYT0-03-12-0064-R 
Cunty, A., Poliakoff, F., Rivoal, C., Cesbron, S., Fischer-le Saux, M. (2015). Characterization of Pseudomonas syringae pv. actinidiae (Psa) isolated from France and assignment of Psa biovar 4 to a de novo pathovar: Pseudomonas syringae pv. actinidifoliorum pv. nov. Plant Pathol. 64:582-9. http://dx.doi.org/10.1111/ppa.12297

Donati, I., Buriani, G., Cellini, A., Mauri, S., Costa, G. and Spinelli, F. (2014). New insights on the bacterial canker of kiwifruit (Pseudomonas syringae pv. actinidiae). J. Berry Res. 4, 53-67. http://dx.doi.org/10.3233/JBR-140073

European and Mediterranean Plant Protection Organization, EPPO Diagnostics PM 7/120(1) (2014). Pseudomonas syringae pv. actinidiae. Boletín 44 (3), 360-375. http://dx.doi.org/10.1111/epp.12171

Everett, K.R., Taylor, R.K., Romberg, M.K., Rees-george, J., Fullerton, R.A., Vanneste, J.L. and Manning, M.A. (2011). First report of Pseudomonas syringae pv. actinidiae causing kiwifruit bacterial canker in New Zealand. Australasian Plant Pathol. Soc. Inc. 6, 67-71. http://dx.doi.org/10.1007/s13314-011-0023-9

Ferrante, P. and Scortichini, M. (2009). Identification of Pseudomonas syringae pv. actinidiae as causal agent of bacterial canker of yellow kiwifruit (Actinidia chinensis Planchon) in central Italy. J. Phytopathol. 157(11-12), 768-770. http://dx.doi.org/10.1111/j.1439-0434.2009.01550.x

Ferrante, P. and Scortichini, M. (2015). Redefining the global populations of Pseudomonas syringae pv. actinidiae based on pathogenic, molecular and phenotypic characteristics. Plant Pathol. 64, 5162. http://dx.doi.org/10.1111/ppa.12236

Gallelli, A., L'Aurora, A. and Loreti, S. (2011a). Gene sequence analysis for the molecular detection of Pseudomonas syringae pv. actinidiae: developing diagnostic protocols. J. Plant Pathol. 93(2), 425-435. http://dx.doi.org/10.4454/jpp.v93i2.1198

Gallelli A., Talocci S., L'Aurora A. and Loreti S. (2011b) Detection of Pseudomonas syringae pv. actinidiae, causal agent of bacterial canker of kiwifruit, from symptomless fruits and twigs, and $\begin{array}{llll}\text { from pollen. } & \text { Phytopathol. } & \text { 462-472. }\end{array}$ http://dx.doi.org/10.14601/Phytopathol_Mediterr-10039

Gonzáles, A. J. and Rodicio, M. R. (2007). Disease of floral buds of kiwifruit caused by Pseudomonas viridiflava and P. syringae. Boletín de Sanidad Vegetal. Plagas (España).

Goszczynska, T., Serfontein, J.J., Serfontein, S. (2000). Introduction to Practical Phytobacteriology. (Bacterial Diseases Unit, ARC-Plant Prot. Res. Inst., South Africa SDC, Swizerland), pp.83.

Kado, E.I and Heskett M.G. (1970). Selective media for isolation of Agrobacterium, Corynebacterium, Erwinia, Pseudomonas and Xanthomonas. Phytopathol. 60, 969-976.

King, E.O., Ward, M.K. and Raney D.E. (1954). Two simple media for demonstration of pyocyanin and fluorescein. J. Lab. Clin. Med. 44, 301-307.

Kiwifruit Vine Health. (2011). KVH Information Sheet: Identification of Psa-V Symptoms, Nov 2011_Version 5 (New Zealand) www.kvh.org.nz/monitoring

Mansilla Vázquez, J.P. and Abelleira Argibay, A. (1999). Presencia de Pseudomonas marginalis y $P$. viridiflava sobre Kiwi en Galicia. Boletín de Sanidad Vegetal. Plagas 25(2), 175-180.

Mazzaglia, A.; Renzi, M.; Taratufolo, M.C.; Gallipoli, L.; Bernardino, R. and Ricci, L. (2010). Cancro batterico dell' actinidia: il punto della situazione in Italia. Rivista di Frutticoltura 9, 66-76. 
Rushing, J.W. (2004). The Commercial Storage of Fruits, Vegetables and Florist and Nursery Stocks. K.C. Gross, C.Y. Wang and M. Saltveit eds. (Kiwifruit In: Agriculture Handbook Number 66), http://www.ba.ars.usda.gov/hb66/kiwifruit.pdf

Scortichini, M. (1994). Occurrence of Pseudomonas syringae pv. actinidiae on kiwifruit in Italy. Plant Pathol. 43(6), 1035-1038. http://dx.doi.org/10.1111/j.1365-3059.1994.tb01654.x

Scortichini, M., Marcelletti, S., Ferrante, P., Petriccione, M. and Firrao, G. (2012). Pseudomonas syringae pv. actinidiae: a re-emerging, multi-faceted, pandemic pathogen. Mol. Plant Pathol. 13(7), 631-640. http://dx.doi.org/10.1111/J.1364-3703.2012.00788.X

Scortichini, M., Ferrante, P., Marcelletti, S. and Petriccione, M. (2014). Omics, epidemiology and integrated approach for the coexistence with bacterial canker of kiwifruit, caused by Pseudomonas syringae pv. actinidiae. Italian J. Agron. 9, 606. http://dx.doi.org/10.4081/ija.2014.606

Servicio Nacional de Sanidad y Calidad Agroalimentaria (2015). Comunicado SENASA: Sur bonaerense: detección de tres muestras positivas de la bacteria PSA en material vegetal de kiwi. http://www.senasa.gov.ar/contenido.php?to=n\&in=11\&ino=11\&io=30050

Takikawa, Y., Serizawa, S., Ichikawa, T., Tsuyumu, S. and Goto, M. (1989). Pseudomonas syringae pv. actinidiae pv. nov.: the causal bacterium of canker of kiwifruit in Japan. Ann. Phytopathol. Soc. Japan 55, 437-444. http://doi.org/10.3186/jjphytopath.55.437

Tyson, J.L., Curtis, C.L., Manning, M.A., Rees-George, J., Snelgar, W. P. and Blattmann, P. (2014). Systemic movement of Pseudomonas syringae pv. actinidiae in kiwifruit vines in New Zealand. New Zealand Plant Prot. 67, 41-47. http://www.nzpps.org/journal/67/nzpp

Vanneste, J.L. (2013). Recent progress on detecting, understanding and controlling Pseudomonas syringae pv. actinidiae: a short review. New Zealand Plant Prot. 66, 170-177. http://www.nzpps.org/journal/66/nzpp

Vanneste, J.L., Giovanardi, D., Yu, J., Cornish, D.A., Kay, C. and Spinelli, F. (2011). Pseudomonas syringae pv. actinidiae in kiwifruit pollen samples. New Zealand Plant Prot. 64, 246251. http://www.nzpps.org/journal/

Wilkie, J.P., Dye, D.W. and Watson, D.R.W. (1973). Further hosts of Pseudomonas viridiflava. New Zealand J. Agric. Res. 16(3), 315-323. http://dx.doi.org/10.1080/00288233.1973.10421110

Young, J.M., Cheesmur, G.J., Welham, F.V. and Henshall, W.R. (1988). Bacterial blight of kiwifruit. Ann. Applied Biol.112(1), 91-105. http://dx.doi.org/10.1111/j.17447348.1988.tb02044.x 